\title{
Devletlerarası hukukun geçirmekte olduğu tekâmül $\left.{ }^{*}\right)$
}

\author{
Yazan \\ Nicolas Politis
}

\author{
Çeviren \\ Dr. Illhan Lütem \\ Devletler H. Asistanı
}

I

Cihan Savaşı, devletlerarası hukukun kiymeti, müessirliği ve hattâ varlığı hususunda zihinleri derin bir şekilde bulandırmıștır. Çiğnenen bu karar antlaşmayı, tanınmıan bukadar kaideyi, milletlerin kendi aralarında bukadar keyfî hareket ettiklerini gördükçe, insan şüphe ve bedbinliğe kapiliyor.

Devletlerarası-hukukun harabisinden, iflâsından, devletlerin faaliyetlerini kesin olarak mecburî mahiyette hukuk kaidelerine tâbi kılmanın imkânsızlığından bahsediliyor.

Fakat bu ilk intiba devam etmemiştir. Ișlenen cinayetlere rağmen ceza hukuku nasıl mer'iyet mevkiinden kalkmiyorsa son harbin ifratlarma rağmen devletlerarası hukukun da ortadan kalkmadiğı hususunu kabul etmek mecburiyeti hasıl olmuştur.

Hattâ bu müşahede savaşın devamı esnasında Sir Frederick Pollock tarafından yapılmıştır: ‘Büyüuk ölçüde dahi olsa ihlâl edildiğinden dolayı hukuk ortadan kalkmaz; nasıl ki bazı câniler takibden kurtuldukları için cezaî adalet ilga edilemezse..."

Durumun daha sakin, daha (objektif) bir tetkiki geçirmiş olduğu imtihanin devletlerarası hukuk bakmindan tehlikeli olmaktan ziyade bu hukuk için çok istifadeli olduğu hususunda kanaat getirilmesini mümkün kılmıştır.

(*) - Bu yaz1, N. Politis'in *Les Nouvelles Tendances du Droit International» adlı eserinin birinci bölümünü teşkil etmektedir. Politis'in hayatı ve eserleri hakkında Ankara Hukuk Fakültesi Dergisinin Cilt III. Sayı I de izahat verilmiştir:

Politis'in yukarda adı geçen eseri Birinci Cihan Savaşından sonra neșredilmiştir. İçindeki yazılar bugün dahi (actuel) bir mahiyet ve değer taşidiklarından bunları kısım kısım tercüme ediyoruz. 
$\mathrm{Bu}$ imtihan, milletlerin hayatinda zaten vukubulmuş olmakla beraber pek farkedilmemiş bazı değişiklikler üzerine parlak bir ışık salmış; büyük adette birçok kaidelerin değerini tecrübe etmek firsatını vermiş; devletlerarası hukukun hiçbir hal çaresine sahip olmadığı birçok meselelerin mevcudiyetini ortaya çıkarmıştur.

Böylelikle devletleraraș hukuk kaidelerinin bilânçosu yapılabilmiş ve şu neticeye varılmıştır: Öyle kaideler vardır ki çok eskimiş olduklarından hakikì olmaktan çımışłar, öyleleri de vardır ki prensip bakımmdan iyi olmakla beraber hâdiselere tam manâsiyle tetabuk edemezler, nihayet, hukukun doldurulması gereken boșluklar arzettiği haller mevcuttur. Bundan böyle, başlangıçtaki ümitsizliğin yerine birdenbire geleceğe güven hissi kaim olmuş ve bu hisse yeni bir devletlerarası hukuk yaratmak temayülü hâkim olmuştur.

Artık bahis mevzuu olan bu hukukun yeniden doğuşu, yenilenmesi, demokratlaştırılması, gelişmesidir.

Yazılar, plânlar, tasarılar birbirini takibetmiştir. Bunlar bilhassa Birleşik Devletlerde pek bol olmuştur. Hakikatte herkes meseleyi aynı açıdan tetkik etmiyor. Bazıları devletlerarası hukukun yeni ihtimallere uydurulmasımı sağllk veriyorlar. Bazıları ise, eski prensiplerin yerine yenilerinin ikame edilmesiyle bu hukukun değişmesini istiyorlar. Maarnafih genel inanç, devletlerarası hukukun gelişmesinin yeni bir safhasına zaten girmiş veya girmek üzere olduğu merkezindedir.

Şen'iyet odur ki, devletlerarası hukuk bilginlerini bu kadar uğraştıran hâdisenin, içlerinden birçoğunun zannettikleri kadar fevkalâde bir mahiyeti yoktur. Bu hâdise devletlerarası hukuk için ne yeni ne de sirf ona hastrr. Bu, hukukun bütün (branşlarma) ait olan sırf nisbî ve gelişmeye müsait olma vasfının basit bir tezahürüdür.

Filhakika hukuk, hayatı̉ aksinden başka bir şey değildir; onun mütemadi değişmelerinin tesiri altında kalır. $O$ da hayat gibi daim bir gelişme halindedir.

Hukuk kaidesi ancak geçici bir sosyal durumu tesbit eder. Çok çabuk eskir.

Hâdiselerin şen'iyeti ile çok zit olduğundan yeni bir formüle yerini terkeder. Fakat bu değişme hiçbir zaman çabuk bir şekilde vukubulmaz, derece derece tahakkuk eder. Eski (formül)ü terketmeden önce onda mevcut en bariz eskiliklerì tashihe yarıacak vasitalarla kullanmaya savaşllır. Ancak tam manâsiyle kullanılmaz bir 
hale geldiğindendir ki yerine yenisi konulur. Fakat zamanla sosyal muhit iptidaî ferdiyetçiliğinden daha gelişmiş bir teşkilâta doğru tekâmül ettikçe, bu teşkilât içinde insanların münasebetleri çoğalır, genişler ve girift bir mahiyet alır, hukuken daha elâstikleşir daha inceleşir, kaideleri daha az devamlıdır. Bunlar daha sık ve daha hızlı bir birlerini takib ederler, çünkü onların hayatın icaplarına intibaklarına daha sık ve daha kuvvetle ihtiyaç hissedilir.

Devletlerarası hukuk bu içtimaî kaidenin dışında değildir. Çünkü, sair hukukî (disiplin) lerden daha az terakki etmekle beraber, onlar gibi aynı menşee, ayn temele, aynı istikamete sahiptir. Fertler gibi, devletler de kendịlerine tanınmış olan hükümleri meşrù bir şekilde ancak kendilerini hissettirdikleri sosyal muhite uygun olarak kullanabilirler. Bu kullanış ancak içtimaî gayelerine uygun olduğu takdirde haklı bir mahiyet arzeder, aksine topluluğun, genel menfaatin zararına vukubulduğu takdirde hukuka aykırıdır.

İmdi, bir asırdır milletlerarası camia dexin bir şekilde değişikliğe uğramıştır.

Milletlerarasındaki münasebetler hiç de eskiden olduğu gibi değildir. Mesafeleri ortadan kaldıran nakil vasitalarının gelişmesi hadisesi bu münasebetleri daha słk, daha muntazam, daha çabuk bir hale sokmuştur. Bundan şu netice doğmuştur: İnsan faaliyetinin bütün sahalarında, iktisadî, fikrî, siyasî sahalarda daha sık, daha geniş, daha girift bağlar yeni menfaatler, ihtiyaçlar, meseleler ve bir bakıma yeni bir zihniyet belirmesine sebep olmuşlardır. Milletlerarası hayatın değişikliğe uğraması tabiî ve kaçınılmaz bir şekilde onu idare eden hukukun değişikliğini tevlit etmiştir. In acele yeni ihtiyaçlara cevap verilmek üzere, devletlerarası hukuku zenginleştirmekte olan yeni kaideler meydana çlkmıştır.

Elli senedenberi muazzam bir yekûna varan antlaşmalar, anlaşmalar her türlü uyuşmalar imzalanmıştır. Fakat sosyal veya ferdî hayatta vuku bulan şey milletlerin birbirleriyle münasebetlerinde de vuku bulmuştur: İnsanın yaşı ilerledikçe, zevkleri, fikirleri, fizik hatları değişmekte devam ederler. Bu değişme her gün vuku bulduğundan ve teferrüatta hissedilir olmadiğından insan onu pek farketmez.

Fakat bir hastalık veya ciddî bir ruhî buhran vuku bulur ve fert farkına varır, ancak değişikliğin anî olduğunu ve başından geçmiș olan hâdise yüzünden meydana çıktığını zanneder.

Hakikatte bu hâdise değişikliğin sebebi değildir. Ancak onu müşahade etmeyi mümkün kllan bir bahanedir. 
Milletlerarası hayatta da vaziyet böyle olmuştur. Devletlerarası hukuk iki nesildir çok değişikliğe uğramıştır. En bariz değişmeleri farketmek mecburiyetinde kalınıyordu. Fakat bu değişmelerin hàricî tezahürünün teşkil ettiği en derin şekil değiş̧irmeler fark olunmuyordu.

Devletlerarası hayatin ve dolayisiyle devletlerarası hukukun temellerinin aynı kaldığı, değişmelerin aynı kalan gẹel kadro içinde vuku bulduğu zehabına düşülüyordu.

1914 çöküntüsü geldi çattı, ciham altüst ederken, sarsintıssna mukavemet edecek kadar hayatiyete malik olmıyan her şeyi sildi süpürdü milletlerin hayat ve haklarının eski kadrosunu tahrip ederken şen'iyetin daha iyi belirmesine yardım etti.

Elli senedir doğmuş olan kâidelerin, sanıldığı gibi, iyice yerleşmiş bir hukukun ekleri olmayı yeni bir hukukun belirtileri olduklarmı meydana koydu, bizi Grotius devrindenberi tamamen esasl1 mahiyette addettiğimiz birçok prensipleri ciddî surette kontrola tâbi tutmağa ve bazan tamamen gözden geçirmeğe mecbur etti. Ezcümle eğemenlik kavramı, eşitlik prensibi, devletlerin hak ve vazifeleri nazariyesi, hattâ devletlerarası hukukun temeli için dahi vaziyet böyle olmuştur.

Bu noktalar üzerinde durmak gerekir, çünkü bunlar geçmişin gelenekleri ile geleceğin istikametlerinin birleşip ayrıldıklan noktaları teşkil etmektedirler.

\section{II}

Eğemenlik kavramı üç yüz ylldır devletlerarası hukukun ilmî yapısına hâkim olmuştur. Bu kavram, devletlerin iç işlerinde olduğu gibi, dıs münasebetlerinde de kendi iradeleri ile kabul ettikleri tahditlerden başkasını kabul etmeksizin hareket etmek mutlak iradesine işaret eder.

Fakat devletlerarası hukuk geliştikçe devletlerin serbest faaliyetleri tahditlere maruz kahyordu.

Bu hâdiseyi (eğemenliği) izah gittikçe daha zorlaşıyordu. Çünkü devletlerin iradeleri hakikaten eğemen olsaydı buyurucu mahiyette kaidelerle sınırlandırılamazdı. Bu çıkmaz karşısında bulunuluyordu, Egemenlik kavramun terki ile devletlerarası hukukun mecburilik vasfi arasında seçim yapmak lâzımdı.

Bazı yazarlar tereddüt etmediler: tercihlerini birincisi lehinde kullandllar. 
Hukuk bir üstün, tabalarına karşı emri olduğundan devletler. arasında hakikì bir hukuk bulunmıyacağı̣nı devletlerin kendilerine kumanda edecek bir üste malik olmadıklarını. iddia ettiler.

Ezcümle John Austin'in meşhur "Lectures on jurisprudence" adlı eserinde izah ettiği nazariye böyledir.

$\mathrm{Bu}$ nazariyenin Almanyada ve sair mahallerde taraftarlar olmuştur, bunlardan sonuncusu lord Birkenhead'dur. Az zaman evvel Amerikan Baro Cemiyetinde demeçte bulunurken mecburî mahiyette bir devletlerarası hukuku kesin olarak reddetmiştir. Fakat genel olarak mantık sahasında bu kađaar ileri gidilmemiştir. Bir yandan devletlerarası hukukun varlı̆̆ı inkâr edilmemiş öte yandan da egemenlik kavramı sun'î bir şekilde terkedilmemiş bu ikisini uyuşturmăga çalışlmıştır.

$\mathrm{Bu}$ yönde birçok izahlarda bulunulmuştur. En fazla itibarı olan egemenliğin tahdidi nazariyesidir.

$\mathrm{Bu}$ nazariye, devletler ancak kendi iradeleriyle bağlandıklarına göre, ancak kendi iradeleriyle kabul ettikleri kaidelere. tâbi olacaklarmı ifade eder.

Böylelikle devletlerarası hukukun mecburilik vasfi onun bir neticesi olduğundan egemenlikle uyuşacaktı.

Devletler menfaatleri gerektirdiğinden kendilerine kanunlari tahmil edebilmek için egemenliklerini kullanacaklardur. kendi (muhtariyet) lerini kendileri tahdid edeceklerdir.

Bu izah hị̧ de tatmin edici değildir, çünkü şayet hukuk kaidesi ancak serbest bir iradenin mahsulü ise esasında mecburi değildir. Onu yaratmış olan devletlerin keyfine tabîdir, çünkü bu devletler mecburi olmadığını arzu ederek onu nazarı itibara almazlar. Bir. iradenin yaptığını aksi bir irade bozabilir.

Filhakika, iradî bir şekilde isdar edilmiş olan kaidelerin iki veya daha fazla iradenin mahsulü olduğu ve bunlardan herbiri tarafından ayrı ayrı bozulamıyacağı söylenmiştir. Fakat bu iradeler anlaşmasına mecburilik vasfını izafe eden mukaddem bir kaidenin varlığını isbat etmek gerekmektedir.

İmdi önceden mevcut olan bu hukukî nizamın kendisi bir iradeler uyuşması üzerine bina edilemez. İzah bir fasit daire içinde dönmekte ve bu çenber içinden çıkabilmek imkânı görülmemektedir. Bu uzlaştırma teşebbüslerinin muvaffakiyetsizliği karş̧ıında egemenlik prensibinin sağlamliğı hakkmnda tereddüt duyulmaya başlanmıştır. Bu prensipte hâkim ve keyfî bir kudret görmekten vazgeçilmiş. Ancak nisbi tahdid edilmiş devletlerarası hukuktan 
doğan bağlamlarla sınırlandırılmış bir egemenlikten bahsolunmuştur. Bu prensibi, görevlerini yerine getirmek ve mukadderatını tayin hususunda devletin ihtiyac1 olan yetkilerin toplumu gibi addetmeğe alışıldı. Fakat bu imtiyazlar kaideyi kurtarmak şöyle dursun onun yikılmasın . daha da hızlaştırdılar.

Filhakika egemenliğin tahdid edilebileceğini kabul etmek onun mevcut olmadığını kabul etmektir, çünkü kaideten bu hiçbir tahdid kabul etmeyen bir kavramdır. İnsan ya bağımsızdır ya değildir.

Hakli olarak sunırlandırılmış bir tâbiyet ifade ettiği söylenmiştir. Böylelikle egemenlik kavrammı tamamen terketmek ve şen'iyeti cepheden karşlamak mecburiyeti hasıl olmuştur.

1914 den evvel başlamıs olan bu gözden geçirmeyi Cihan Harbi kat'î ve acele bir şekilde emretmiştir.

Çünkü harp yalnız, devletlerin birbirlerine karşı olan bağlı1]klarım şaşlacak bir surette ortaya koymakla kalmamıs, milletlerarası anarşiyi dưrdurabilmek için devletlerin samimî olarak kanuna boyun eğmeleri ve şayet aralarından hiçbiri diğerine hükmedemezse hepsinin itaat etmeleri lâzım gelen hukukta müssterek bir üstleri olduğunu kabul etmeleri gerektiği hususunu da belirtmiştir.

Milletler Cemiyetinin kurulması bunun isbatını tamamlamak hususunda yardım etmiştir.

Milletler Cemiyetinin, bir teşkilâta bağlanması hususunda ilk denemeyi teşkil ettiği milletlerarası hayat millî ferdiyetçiliğ̀i coşturan ve mümkün kılan egemenlik kavramı ile kabili telif değildir.

Mesele o derece endişe verici bir hal almıştır ki hemen hemen bütün devletlerarası hukuk yazarları onunla meşgul olmuşlardır.

Harptenberi, hemen bütün memleketlerde ezcümle Birleşik devletlerde birçok (etüdlere) mevzu teşkil etmiş ve bu çalışmalar, umumiyetle manâdan ârî, tehlikeli ve milletlerarası anarşanin devamina yardım ettiğinden, kabul edilmez bir kavram olan egemenliğin kat'î reddi neticesine varmışlardır. Şen'iyeti görebilmek için egemenlik perdesi kaldırıldığında devletlerin sözde bağımsızlı̆̆ınm hukuk tarafından tesbit edilmiş sınrlar dahilinde serbestçe hareket etmek yetkisinden başka bir şey olmadığı anlaşılır; bu hükûmetlerin devletlerarasi hukuka istinaden haiz oldukları bir nevi özel yetkidir.

Böyle anlaşıldığında Devletlerin hürriyeti fertlerinki ile mukayese edilebilir.

- $\quad \mathrm{Bu}$ hürriyet egemenlikten derin bir şekilde ayrilır. Mutlak ol- 
mak şöyle dursun esaslı bir şekilde nisbidir, değişebilir ve sonsuz tahdidleri haizdir.

Milletlerarası münasebetler nekadar fazla gelişirse milletler okadar az hür olurlar.

Tesanütlerinin kaydettiği her terakkiye hürriyetlerinin yeni. bir sinirlandırılması tetabuk eder. Maamafih bütün hareketlerinin tahdid edilebilmesi için daha zaman lâzımdır.

Öyle faaliyetler vardır ki, daha devletlerarası hukukun hükmü altına girmemişlerdir. Devletlerin mahfuz sahasını teşkil ederler, onların münhasır selâhiyetine taallûk eden iç işlerini ihtiva ederler.

Milletler Cemiyeti Misakının 15. inci maddesinin 8 inci fukrasında işaret edilmişlerdir. Fakat burada değişmez hiçbir şey yoktur. Aksine mahfuz saha'nin muhtevası tamamen değişen bir mahiyet arzeder.

Milletlerarası Daimî Adalet Divanının çok doğru müşahedesine göre (7 şubat 1923 mütalâası) mahfuz saha milletlerarası münasebetlerin gelişmesine ve devletlerarası hukukun kaydedeceği terakkilere bağlıdır. Ahvale göre değişikliğe uğrar. Biri diğerini takiben ị̧ işler dahili münhasır selâhiyetlerin kurtularak muayyen bir milletlerarası vasif elde ediyorlar. Îște devletlerarası hukukun maruz kaldığı ve hukukî bir önemi olan değişiklik budur. Devletlex hukukunun yönelmeğe başlamış olduğu bu değişiklikler istikametleri görmeğe engel olan kalm perdeyi ortadan kaldırmaktadır.

İlmî araştırmaları ve milletlerin meşruiyetin genişlemesi hususundaki gayretlerini kolaylaştırmaktadır. Onun mantıkî neticesi olan başka değişiklikleri izah etmekte, veya hazırlamaktadır.

III

Önce devletlerin eşitliği prensibinde vaziyet böyledir. Egemen devletler arasında eşitlik sert ve mutlak bir şekilde anlaşılmak gerektirdi.

Bir devlet, zahirî dahi olsa kendisine yapılan muamelede eşitsizliğe uğramayı hiçbir surette kabul edemezdi.

Fakat tatbikat nazariyenin aksini gösteren birçok misaller veriyordu. Tatbikat, bir nizam ve düzen ihtiyact dolayısiyle, birçok bakımlardan büyük devletlerle daha az önemli devletler arasinda bir tefrik yapmiştır.

Misal olmak üzere şu iki halle iktifa edjlebilir: 
1815 ve 1818 Viyana ve Aix-La Chapelle kongrelerinde tâyin edilmiş diplomatik sıra meselesinde Büyük Elçi adını alan büyük devletlerin temsilcileri, diğer devletlerin elçi ve fevkalâde temsilcilerine takaddüm ediyorlar ve 1907 de kurulmasi tasarlanan milletlerarası ganaim mahkemelerinde devrin sekiz büyük devletinin daimî üyeliklerine mukabil diğer devletlerin eşit olmayan bu usuliyle temsil ediliyorlardı. Eşitlik kaidesine vuku bulan bu istisnalar, buna kattanmak zorunda kalan memleketlerde bir kuvvet suiistimali addediliyor, ve onlarm adalet hislerini isyan ettiriyordu.

Bundan, milletlerarası teşkilâtın terakkisine az müsait olan bir ruh haleti doğuyordu. 1907 senesinde bir hakem mahkemesi kurmak tasarısı, milletlerarası ganaim mahkemesinde eşit olmıyan bir şekilde temsil edilmek zorunda birakılan ikinci derecede devletler tarafından kabul edilmediği için suya düştü. Aynı. his, siyasî konferansların tamamını muvaffakiyetsizliğe uğramasına sebep olmuştur. Azlığın can kurtaranı gibi telâkki edilen ittifak kaidesi eşitlik fikrinin mübalağa edilmesi yüzünden ekseriyete karşı kullanılan despotça bir silâh olmuştur.

Azınlık, oy veren çokluğa hasredilse dahi, bir konferansta karar alınabilmesine itiraz edebilmek iddiasını ortaya atmış ve buna sebep olarak böyle bir kararın haiz olacağı manevî kuvvetin zamanla kendi mukavemetini yeneceğini öne sürmüştür.

(Yarı-Itttifak) denilen usul'de bir anlaşma zemini bulmaya boşuna uğraşılmıştı. Bu usulde çoğunluğun bir kararı ancak azınlık itiraz etmediği takdirde konferans kararı olarak kıymet ifade edecektir. Fakat azınlık buna riza göstermemekte serbest kaliyor ve bu devletin ayak diremesi diğerlerinin konferans namına bağlanmalarına mâni" olabiliyordu.

Bunun bàriz bir misaline La Haye İkinci Barış Konferansında rastlanmıştır. Konferansta temsil olunan devletlerin büyük çoğunluğu mecburi tahkimin lehinde karar vermişlerken Almanya ve az sayıda daha birkaç devlet buna tarafuar olmamıslardır. Aleyhte bulunanların ekserisi çoğunluk üyelerinin kendi aralarında birleşmelerine itiraz etmiyorlardı. Fakat Almanya başka türlü düšünüyordu. Onun müracaatı otuz iki devletin bir anlaşmaya varmasına mâni oldu. Egemenlik Kavramının terki ile, devletlerin eşitliği tamamen veçhe değiştirmektedir. Bu eşitlik bir devlet dahilinde vatandaşlar arasındaki eşitliğe benzer bir hal almaktadır. Onunla aralarındaki farkın, milletlerarası düzenin daha az tekâmül etmiş bir seviyede olmasindan ileri gelen farklardan ibarettir. 
Eşitlikten hukukî ve kanunî eşitlik anlaş̧ılmak lâzımdı̀.

Devletlerarası hukuk karşısında devletler bu hukukun himayesini talepedebilmek ve ona boyun eğmek bakımından eşittirler. Fakat maddî ve manevî sahada eşitlik mevcut değildir. Devletler arasında, fertler arasında olduğ gibi saha ve nüfus, zenginlik ve kuvvet, kültür ve nüfus bakımmdan en büyük eşitsizlik hüküm sürer.

Bütün bu bakımlardan her zaman için büyük ve küçük devletler mevcut olacaktrr.

Eşitlik, Milletlerarası camianin menfaatlerinin idaresi ile görevlendirilmiş uzuvların çalışmasına ve teşebbüsüne iştirakte eşitliği de gerektirmez. Bu halen (doktrin) ce kabul edilmiş bir kaidedir.

Bu kaide yedi sene evvel, Milletlerarası Hukuk Birliği tarafından daha sonra bahsedeceğimiz devletlerin hak ve vazifeleri beyannamesinde sarih bir şekilde ifade edilmiştir.

Maamafih tatbiki bir bakımdan milletlerarası teşkilâtın aksaklıklarından diğer ve daha ehemmiyetli bir bakımdan ise egemenlik kavramını, milletlerin zihniyetinde birakmış olduğu köklerden ileri gelen birçok güçlükler tevlit etmektedir. Teşkilât ihtiyacımın kuvvetle hissedildiği ve bazı tedbirlerin devletlerin çekingenliklerini gözetmek imkânını verdiği hallerde milletlerarası işlere eşit olmiyan bir surette iştirak şekli galip gelmiştir. Bunun bariz misalini Milletlerarası Daimî Adalet Divanı teşkil eder. Burada 15 üyelikten beşi büyük devletlere ayrimış diğer iştirak eden devletlerin yekûnu -ki bugün elliden fazladır- on ïyeliği aralarında paylaşmak zorunda birakılmıştır.

Şayet 1907 'de imkânsız görülen bir hal tarzı 1920'de kabul ettirilebilmişse bunun sebepleri önce bir daimî mahkemenin lüzumunun daha iyi anlaşlmış olması ve bilhassa iki uzvu ile yani Assamble ve Konsey ile Milletler Cemiyetinin eşitlik adına küçük devletlerin talep ettikleri yargıçların seçimini teşkilâta bağlamış olmasıdur, öyle ki bu seçim büyük devletlere daima menfaatlerinin üstünlüğünün gerektírdiği hal tarzlarını sağlamaktadır. Aynı cinsten düşünceler Milletler Cemiyeti Konseyinin bugünkü teşkilâtının kabulïnü sağlamıştır. Burada daimî dört üyeliğin bihakkın büyük devletlere ayrilmasina mukabil, geri kalan dokuz üyelik Cemiyetin bütün üyeleri arasında seçimle belli olur. Fakat burada büyük devletlere tanman imtiyazlı mevki küçük devletlerin eşitlik isteyen hislerini rencide edecek derecede bariz bir mahiyet arzetmektedir. Gittikçe kuvvetlenen demokrasi düşüncesine aykırıdır. Gelecekte, kon- 
seydeki bütün üyeliklerin seçimle tesbit edileceği ümit edilmektedir, fakat bu gelecek pek uzak gözüküyor.

Büyük devletler bazı imtiyazlarından öyle çabuk vazgeçeceğe benzemiyorlar. Kaldıki - bir bakıma doğru olarak - bu durumun tamamen haklı olduğunu iddia ediyorlar onlarm hususî vazife ve mes'uliyetleri bulunduğundan bunlara mantıkan hususî haklar karşı çıkarılmak gerektir.

Milletlerarası teşkilât, bugün hemen sırf üyelerin bazıları tarafindan taşınan yïkü topluluğa dağıttıkça hakikí bir demokratlaşmayı iddia edemez.

Zaten imtiyazlarm kalkmasindan sonra dahi devletlerin milletlerarası kamu hizmetlerine eşit olmiyan bir şekilde iştiraklerini mazur gösterecek hir sebep kalacaktır ki bu sebep iç hizmetlerinde görülen eşitliği izah eder.

Bu hizmetlerin görülmesi, mutlaka herkeste bulunmayacak olan kabiliyet ve dirayeti gerekleştirmektedir.

Eşitlik prensibinin nasıl mütalâa edilmesi yolunda söylenen şeyler fiiliyatta ittifak kaidesinin arzettiği güçüklerin kavranmasina Devletlerin egemenliğini ve eșitliğini bahane ederek milletlerarası bir teşkilâtta her önemli kararın ittifakla alınacağını prensip olarak vazetmek, devletlerarasında hiçbir ciddî teşkilâtın kurulamıyacağını kabul etmek demektir, çünkü ittifak kaidesi bir felç ve anarşi sebebi olabilir.

1926 senesi mart ayında Milletler Cemiyetinde vuku bulmuş olan hâdise bunu pekâlâ göstermektedir. Şüphesiz, milletlerarası teşkilâtın bugünün durumunda ittifak kaidesini tamamen ortadan kaldırmak imkânsızdır; çünkü öyle haller vardır ki bu kaide devletlerin ana hürriyetleri için lüzumlu bir teminat teşkil etmektedir, Fakat bu haller dışında onun bertaraf etmekten ancak fayda hasıl olur.

Şimdiden birçok hallerde Milletler Cemiyetinde çoğunlukla iktifa olunulmaktadır.

Daha bazı haller vardır ki böyle olması gerekir, çünkü devletlerin ana hürriyetleri bahis mevzuu olmamaktadır.

Böylelikle ittifak kaideleri sahası ile iç işler sahası arasında sıkı bir rabıta bulunmaktadır. Biri diğerine bağhıdır.

Devletlerarasi hukukun ilerlemesi sayesinde birisi darald $1 \mathrm{mI}$ diğerinin de aynı şekilde daralması lâzımdır. 
IV

Bir diğer değişme de devletlerin hak ve görevlerinin tesbiti meselesinde müşahade edilebilir. XVII. yüzyllda egemen devletler kavramı teşekkül ettiğindenberi devletlerarası hukukun bütün doktrini tabîi hukuk nazariyesinin tesiri altında kalmıştır. Devletler camiası, taraflarca serbestçe rıza gösterilmiş bir mișaka dayanıyordu. Her devlet topluluğun faydası için devrettiği kısım müstesna olmak üzere tabiat'dan edihdiği hürriyeti muhafaza ediyordu.

J. J. Rousseau'nun İçtimâ̂ mukaveleșindeki insan gibi, Devlet. ait olduğu cemiyete karşı önceden ve üstün bazı haklara malikti. Temel haklar denilen bu haklar kendilerine sahip olanların kesin iradesi olmaksızm devredilemez ve mutlak addedilirdi. Antlaşmalardan doğan nisbî ve ikinci derecede haklara zıt idiler. Sırf ferdiyetçi olan bu doktrinde devletlerarası hukukun yegâne görevi temel hakları birbirleri arasında uyuşturmaktan ibaretti.

$\mathrm{Bu}$ hakların adedi hakkında olduğu kadar onlara tekabül eden görevler hakkında da en büyük tereddüt hakimdir. Fransız İhtilâli zamanında papaz Greguar bir beyannamede devletlerin hak ve vecibelerini tesbit etmek gibi övülecek bir teşebbüste bulunmuştur. Fakat 1793 de millî Konvansiyon'a tevdi edilen tasarının arkası gelmedi, her yazar keyfi nasil isterse temel hakların az veya çok uzun olan bir listesini tesbit ediyordu. Genel olarak bahis mevzuu edilen ilerleme veya tekâmül hakkı idi.

Görevlere ayrılan saha çok dardı. Ekser zamanlar bunların haklarla at başı oldukları söylenmekle iktifa ediliyordu. Bir devlet için hak olan diğerleri için görevdi. Bazan karşllıklı yardım görevinden, müdahalede bulunmamak görevinden dış memlekette uyrukları himaye görevinden bahsolunuyordu.

Bu sayışlar, tasnifler yapllnca, bu tasnifler içine, istensin istenmesin, aklî taksimlerin gerektirdiği ilmî araştırmaya ve hukuk kaideleri ile felsefî temayüller arasındaki ayırmaya pek önem verilmeksizin bütün milletlerarası meseleler ithal ediliyordu.

XIX'uncu yüzyılda teamülì hukukun gelişmesi ile bu doktrinin sun'î ve kısır mahiyeti ciddî bütün müşahitlerin nazarı dikkatini celbetti. Birçok memleketlerde temel haklar doktrinine karşı bir tepki belirdi. Doktrinin içtimai olmayan bir temele dayandığını göstererek reddettiler. Bu doktrin devletlere, devletler câmiasından önce mevcut haklar atfediyordu. Halbuki, kaideten, hukuk bir içtimaî mahsuldür. Sosyete dışında mütalàa edilemez. Aleyhinde bulunan doktri- 
nin 2ıddına olarak şöyle deniliyordu: Devletler ancak kendi iradelerinin uyuşmast neticesinde meydana çıkan haklardan başkalarına sahip olamazlar. Tenkidin hareket noktası doğru ise de vardığı neticeler pek sağlam değildir. Uyuşarak (objektif) kaidelere vücut veren iradelerin keyfì olmadıklarını kabul mecburiyetinde kalınyordu. Bu jradeler fayda ve amelî ihtiyaç düşüncelerine boyun eğerler. Bir amerikalı profesörün tabiri ile (by necessary implication) birbirleri ile buluşurlar. Bu demektir ki milletlerarası camiaya kabul edilir edilmez her yeni devlet hadiselerin kúvveti tesiri ile onu idare eden kaideleri kabul etmek mecburiyetindedir.

$\mathrm{Bu}$ kavis sayesinde bazı yazarlar temel haklara yeni bir mânâ vererek canlandırmayı düşünmüşlerdir. Bunları cemiyetden evvel mevcut tabiî bir takım haklar addetmektense devletlerarasında hukukî bir sosyetenin mevcudiyetinden doğan müsbet haklar olarak ortaya çıkmaktadır. Ezcümle Milletlerarası Fukuk Birliği önünde açıklanan tez böyledir. Eski hatalara mukabil bu inkâr kábul etmez bir ilerleme arzetmektedir. Devletlerin hakları artık ahlâkî prensipler değil, fakat hukuk kaideleridir. Eskiden mutlak mahiyette olan irade anlaşmalarınca tahmil edilen sımrlardan başkasına rastlamayan bu haklar şimdi nisbî olup kendilerine vücut veren sosyal amaca karşı sorumludurlar. Başka deyimlerle, ferdiyetçilik üzerine bina edilmelerine mukabil, bundan böyle tesanüde dayańdırılmaktadırlar. Bu zihniyetle devletlerin hak ve görevlerini, milletlerarası camianın anayasasını teskil edecek olan, bir beyannamede tesbit etmek yolunda teşebbüslerde bulunulmuştur. Bu yola Amerikan Devletler arası hukuk Enstitüsü, ilk olarak 1916 senesinde girmiștir. Enstitü metnini Amerikan devletlerarası hukuku taknini tasarısına sıkıştırılmıs olan bir beyanname ortaya koymuștur. Bu teşebbüsü 1916 da daha geniş bir ölçüde olmak üzere Devletlerarası Hukuk Birliğinin teşebbüsü takip etmiştir. 1921 den itibaren Devletlerarası Hukuk Enstitüsü de hazırlıyacağı beyannameyi diğer iki beyanname ile tek bir metin haline sokmak ve devletlerin tasdiklerine sunmak niyeti ile mesele ile meşgûl olmuştur. Nihayet 1926 da Parlamentorlararası Birliğin hukukî komisyonu tarafından da diğer bir beyanname tasarısı kabul edilmiş̧îir.

Bu gayretler manidardır. Doğmakta olan millerlerarası teșkilâta bir anayasa temin etmek ve bunun baş tarafina milletlerin hak ve görevleri beyannamesini yerleştirmek ihtiyacına itaat etmektedir. Bununlaberaber hernekadar egemenlikten sarahaten bahsetmemekle beraber daima onun nüfuzu altında kalıyor, milletlerarası câmia- 
nin ve hukukun temeline devletlerin iradelerini yerleştiriyorlar. Devletlerin kişiliklerinden doğan haklardan bahsettiklerine göre bu kişiliklerin mevcudiyetini kabul ediyorlar.

Imdi, kişilik, artık hiçbir fayda arzetmeyen basit bir mevhumeden ibarettir. Şüphesiz, geçmiște egemenlik gibi, inkâr kabul etmez hizmetler etmiştir. İnsanlarm devletin durumunu daha jyi anlamalarını mümkün kılmıştır. Devletin yalnız hakları değil vazifeleri de mevcut olduğunu ve herbirinin hukuk kaidelerine tâbi bulunduğunu göstermiştir.

Gerek iç, gerek diş kamu münasebetlerinde eşitlik kavramını sokmakta âmil olmuştur. Fakat devlet tarafından güdülen amaçlara erişilince veya hiç olmazsa millî veya milletlerarası hayatın ihtiyaçları olarak doğrudan doğruya nazarı itibara alınmea şimdiye kadar egemenlik kavrami ile birlikte onlara dayanarak vazifesini görmüş olan kişilik kavramı faydasız ve hattâ tehlikeli bir hal almıştır. Bu kavram, uzvi bakımdan olduğu kadar hukukî bakımdan da tamamen yanlıştır. Uzviyetçilik isbat edilemiyecek fikir - ötesi bir hipotezdir. Müşterek irade adı verilen şey hakikatte onu başka kişiler arasında paylaşmıya muvaffak olan muayyen kişilerin şahsî iradelerinden başka bir şey değildir.

Hukukî şahsiyete gelince, o da uzvî şahsiyet kadar vâkıalarla uyuşamaz bir hal arzeder. Filhakika hakikî bir fasit daireye istinat etmektedir.

Çünkü inşaî unsuru yani kanunu tahakkuk ettirebilmek için kissi olarak hareket eden devletin müdahale ettirmek lâzımdur. Imdi, devlet kişi olarak ancak şahsiyetinin bir unsuru zaten kendisi tarafından yaratılmış olsaydı var olabilirdi. Şen'iyet gösteriyor ki devletin iradesi denilen şey idare eden insanların iradeleridir. Devletin kişiliği idare edenlerin tasarruflarmı onların hususî tasarruflarundan ayrıldığmı anlatmak için kullanılan bir (metafor)dan başka bir şey değildir. Fakat haddizatında (metafor) un kendisi faydasızdır. Çünkü idare edenlerin resmî veya hususî tasarruflarını tefrike yarayan şey, onların hareket ederken öne sürdükleri vasıf değil hangi hukuk kaidesine istinat ettikleridir. Durum böyle olursa fertler için nasll mevcut değilse devletler için de subjektif haklar mevcut değildir. Ancak ve yalnız fertlere hitap eden ve onların tasarruflarının kanunîliğini takdire yarayan (objektif) kaideler vardır. Bundan böyle devletlerin hak ve görevlerinden bahsolunacağına bir devletin idarecileri olarak faaliyette bulunan insanların șu veya bu hareketlerine müsaade eden veya men'eden (objektif) kaideler 
mevcut olduğunu söylemekle ilmî hakikate daha çok yaklaşılmış olur.

$\mathrm{V}$

Egemenlik ve onun ikizi kişilik kavramanm terki bizi nihayet devletler hukukunun mesnedi üzerine olan fikirlerin tetkikine sevkeder.

Devletlerin egemenliklerini muhafaza etmekle beraber mecburî hukuk kaidelerine tâbi kalmaların izah için uzun müddet serbest bir şekilde ifade edilen irade fikrine başvurulmuştur. Bu izah şekli aym zamanda iç hukuka da tatbik edildiğinden daha kabul edilebilir bir mahiyet arzediyordu. Vatandaşların genel tasvibi nasıl iç hukuka vücut veriyorsa devletlerin rizası da devletler hukukuna mesnet teşkil ediyordu.

Fakat bu izah her iki halde de şu mülâhazalarla karş̧laşıyordu: İradeler anlaşmasımın kendi mecburî olma vasfını edindiği içtimaî mukavele mütearifesi ile; devletin kişiliğine atfedilen $-\mathrm{ki}$ bu da bir mevhumeden ibarettir-- bir umumî irade mevhumesi ile; kabul olunsa dahi bu iradenin tamamen serbest olmayp pratik ihtiyaç ve fayda düşüncelerine tâbi olduğu müşahedesi ile. Bu takdirde, insanda devletler hukukunun bu izahında, zevahirin şen'iyetle, şeklin esasla, hukukun büründüğ̈̈ kallğın onun hakikî varlı̆̆g ile karıștırılıyormuş gibi bir his uyanıyordu.

$\mathrm{Bu}$ karıştırma devletlerin rıalarına istinat eden müsbet hukukun keyfí olamıyacağın, tabiat ve ahlâkın yüksek emirlerini tahakkuk ettirmeğe memur olduğunu izah eden tabiî hukuk doktrini tarafundan şöyle böyle farkolunmuştur. Fakat bu doktrinde, bu ideal hukukun ne varlığ́ ne de onu müsbet hukuka rapteden bağlar tasrih ediliyordu.

Maamafih, bunda hâddiselerin müsbet bir şekilde gözetilmesi ile meyvalarını verebilecek velût bir fikir mevcuttu.

Filhakika şen'iyetin dikkatli bir tetkiki hukukun sosyal ihtiyaçlarm yardttiğı 'tesanüdün bir neticesi olduğunu gösterir: her toplulukta insan münasebetleri ahlâkî ve iktisadì faaliyetler yaratrrlar, ilgililerde bunlara ittiba etmek hissi yerleşince derhal mecburî mahiyette hukuk kaideleri halini alırlar ve şayet ilgililer bu ittibada bulunmazlarsa, zihinlerde bu kaidelerin fiilî müeyyidelerinin tahakkukuna âmil olacak bir tepki belirir. Hukukun bu sosyoloiik olus şeklinin tahlili ilk defa 1848 de mülkiyet hakkı dolayısiyle Renan tarafından yapılmıştır. Bu yüzylın başında Duguit'ye, rıza 
nazariyesinin yerini almak temayülünü gôsteren bir hukukî doktrin ilham etmiştir: bu doktrine göre hukuk ne bir nizamin meydana çıkması, ne bir irade tezahürüdür; hukuk sadece içtimaî bir olgu, şuûr kesbetmiş bir hâdiseden ibarettir; içinde doğduğu cemiyetin idarecileri onu kanunlarla veya antlaşmalarda ifade ile iktifa ederler. Bu anlayışa göre devletlerarası hukukun tek bir kaynağı mevcuttur: devletlerin tesanüdünden neş'et eden iktisadî ve ahlâkî kaidelere mecburîlik vasfını izafe eden milletlerin hukukî şuuru.

Adet ve antlaşmalar şimdiye kadar sanıldığı gibi hukukun kaynakları değil, fakat müşahade usulleridir. Bu usulleri yalnız bunlarin teşkil etmedikleri de ilâve edilebilir. Bir devletler hukuku kaidesinin varhğg âdet ve antlaşmalardan müstakil olarak başka usullerle de isbat edilebilir.

Böylelikle, âdetin ve antlaşmaların tesirlerine müteallik birçok meseleler daha iyi anlaşllabilir.

Irade nazariyesi, àdete atfedilen umumî tesiri izah için epey güęlük çekmekte, âdetin, zımnî bị şekilde iştirak ettikleri farzolunan bütün milletler için muteber olduğunu söylemekle iktifa etmektedir. Hukukî şuur doktrininin bu mevhumeye ihtiyacı yoktur: Hukuk kaidesi, kendisine vücut veren hukukî şuurun teşekkül ettiği içtimaî muhite ait olan bütün milletler için — haricî tezahürü bu milletlerin ancak birkaçının münasebetinde belïmiş olsa dahi- mecburîdir.

Bu hal bazı âdetin umumî olacak yerde ancak bir kıt'aya, mevziî veya mahallî bir kuymet arzedişini izah eder.

Antlaşmalara gelince, yeni doktrin pratik mahiyette çok önemli neticeler tevlit eder. Birincisi, antlaşmaların akdinin kanunların yapılışında olduğu gibi keyfî bir şekilde vukubulmadığıdır. Bunu nizamlandıran sosyal ihtiyaçlardır, bu ihtiyaçlarm varlığını belirtmek ise hükûmetelere vergidir. Hükûmetler zaten vücut bulmuş kaideleri müşahade de geciktikleri veya daha meydana çlkmamış olanları ifade etmekte acele ettikleri takdirde görevlerini yerine getirmemiş olurlar. Bundan şu netice çıkar ki şayet antlaşma maddî kıymetten mahrumsa devamh olamaz ve aksi istikamette olarak zaten mevcut olan bir kaideyi ilga edemez. Aynen, bir antlaşmanm feshi kendisi tarafından ifade edilmiş kaidenin muhakkak ortadan kalkmasm in icabettirmez; bu kaide var olmakta devam eder. Bir antlaşmanin tasdik edilmemesi bu antlaşma tarafından müşahede edilen mukaddem kaidenin kıymet ifade etmesine mâni olmaz.

Nihayet, antlaşmaların nisbî tesirleri onlar tarafından isđar edilen kaidelerin ruhuna değil, şekline taallûk eder. 
Bu kaideler yeni şekilleri ile üçüncü şahıslara karşı dermeyan edilemezlerse de, bu şahıslara karşı âdet kaideleri veya hukukun umumî prensipleri olarak mecburî mahiyet arzederler.

\section{VI}

Bu izahlar müșahede edilen değişikliklerin muazzam tesirleri hakkmnda bir fikir verebilir.

Veçhe, kuymet, metod değiştiren bütün devletler hukukudur. $\mathrm{Bu}$ hukuk, diğer hukuka benzer bir hal ahyor. Bir memleket vatandaşları hakkında zaten câri olan meşrûiyet rejimini milletler için de tesis ediyor.

Milletlerarası câmianın, her cemiyetin hedefini teşkil eden: nizamm, barışin ve adaletin muhafazası hususlarını elde etmesine yardim ediyor. 